\title{
MEASUREMENT OF SMALL QUANTITIES OF INSULIN-LIKE ACTIVITY USING RAT ADIPOSE TISSUE. I. A PROPOSED PROCEDURE *
}

\author{
By ALBERT E. RENOLD, DONALD B. MARTIN, $\dagger$ YVES M. DAGENAIS, $\ddagger$ \\ JURGEN STEINKE,§ RITA J. NICKERSON AND MINDEL C. SHEPS \\ WITH THE TECHNICAL ASSISTANCE OF VILMA LAURIS
}

\author{
(From the Departments of Medicine, Harvard Medical School and the Peter Bent Brigham \\ Hospital, the Department of Preventive Medicine, Harvard Medical School, and the Baker \\ Clinic Research Laboratory, New England Deaconess Hospital, Boston, Mass.)
}

(Submitted for publication February 8, 1960; accepted May 19, 1960)

In the absence of sufficiently sensitive methods for the chemical determination of insulin, attempts to measure insulin in biological fluids have been almost entirely limited to bioassay procedures and, more recently, to immunological techniques. The bioassay procedures used have been based on the hypoglycemic effect of insulin in animals whose sensitivity was increased by endocrine manipulation (1-3) or on the effects of insulin on isolated tissue, in particular the mammary gland of lactating rats (4), and the diaphragm of rats (5-8) or mice (9). The largest body of information currently available concerns procedures based upon the effect of insulin on glucose uptake by rat diaphragm muscle (10).

The observation that isolated adipose tissue not only responds directly to insulin (11-13), but does so at very low insulin concentrations $(14,15)$, has indicated the possible usefulness of this tissue for the measurement of small quantities of insulin (15). It is the purpose of this and the following paper to present the information which has been accumulated in this laboratory over the past three years, during an attempt to elaborate and evaluate a suitable procedure, which might in time become applicable to tissue extracts or to biological fluids such as serum. Whenever applied to materials other than solutions of pure insulin, the term "insulin-like activity" (ILA) will be used in pref-

* Supported in part by grants in aid from the Adler Foundation, Inc., Rye, N. Y., Eli Lilly \& Co., Indianapolis, Ind., and the Rear Admiral W. L. Capps Fund, Harvard Medical School, Boston, Mass.

$\dagger$ Recipient of a research fellowship from the United States Public Health Service.

$\ddagger$ Recipient of a research fellowship from the R. Samuel McLaughlin Foundation, Toronto, Ontario.

$\S$ Recipient of a research fellowship from the American Diabetes Association. erence to the terms "insulin," "insulin-activity," or "effective insulin activity."

Being well aware of the many questions which are properly raised when a sensitive bioassay procedure is introduced and its application to complex solutions such as serum is suggested, the authors would like to separate the procedure itself from the question of its applicability to serum. This first paper will report the studies designed to select a procedure suitable for detecting small amounts of pure insulin. The second paper will present an analysis of the routine performance of the procedure when applied to solutions of pure insulin and to more complex solutions, using selected serum samples as specific examples.

\section{METHODS}

\section{Selection of a suitable metabolic index}

It is now established that, in the presence of insulin, adipose tissue incubated in vitro utilizes more glucose (11), incorporates more glucose into glycogen (16), oxidizes more glucose carbon to $\mathrm{CO}_{2}(13,16,17)$, and incorporates more glucose carbon into fatty acids (13, 17) and glycerol (16). Furthermore, since insulin markedly increases overall $\mathrm{CO}_{2}$ production (18) while affecting oxygen consumption only to a small degree $(12,18)$, the presence of insulin increases net gas production by this tissue. Any of these metabolic effects of insulin could be used as indices of ILA in a bioassay procedure. In this laboratory, some experience has been gained with the use of increased glucose uptake as an index for ILA (15), and Beigelman $(19,20)$, as well as Humbel (21), has published data concerned with the evaluation of a measurement based on glucose uptake. This measurement requires meticulous care in the handling of glucose estimations, since it frequently represents a small difference between two independent glucose measurements, each with its inevitable error. Ball, Martin and Cooper (18) have suggested that the use of net gas production by adipose tissue for the measurement of ILA would allow for the metabolic characterization of each tissue before the addition of insulin standards or unknown solutions, as 


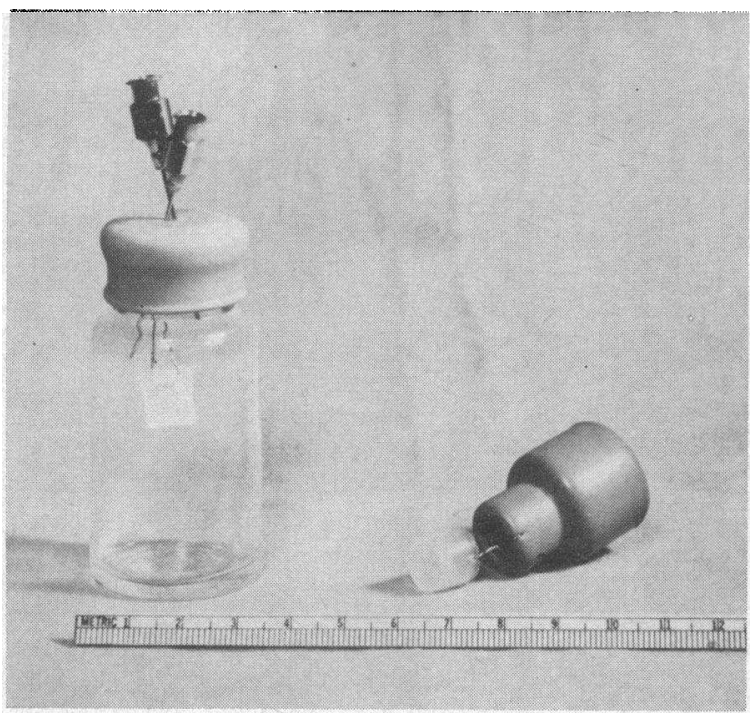

Fig. 1. INCUBATION FLASK USED IN THESE STUDIES.

well as for its final characterization regarding its maximal responsiveness to insulin.

Among the other indices mentioned, $\mathrm{CO}_{2}$ production from glucose carbon and incorporation of glucose carbon into fatty acids show the most favorable dose response relationships, i.e., the steepest dose response curves associated with similar precision (22). Of the two, $\mathrm{CO}_{2}$ production from glucose labeled with $\mathrm{C}^{14}$ is more convenient as a measurement, since the procedures involved require less time and since less radioactivity is required because dilution of the labeled glucose in the large pool of adipose tissue lipids is avoided. Accordingly, the index which has been selected for the experiments reported here has been that of the formation of $\mathrm{C}^{14} \mathrm{O}_{2}$ from glucose labeled with $\mathrm{C}^{14}$. Glucose-1-C $\mathrm{C}^{14}$ has been used in preference to uniformly labeled glucose, since the oxidation of this carbon is particularly affected by insulin $(17,23)$ and since, as will be discussed below, the oxidation of this carbon is less affected by other metabolic agents such as epinephrine (24) or growth hormone (25).

\section{Description of the procedure used}

Animals and tissues. The animals used were male albino rats of the Wistar strain (Harvard Biological Laboratories and Albino Farms) fed ad libitum on Purina laboratory chow, weighing between 200 and $260 \mathrm{~g}$. They were kept in individual cages for 2 to 5 days prior to use between 8 and 9 a.m. The tissue used was epididymal adipose tissue.

Incubation flasks. The flasks used for incubation were ordinary glass bottles with a total capacity of $35 \mathrm{ml}$. They were stoppered with sleeve-type rubber stoppers, the inner sleeves having a diameter of $25 \mathrm{~mm}$. Small plastic cups (1 cm diameter and $1 \mathrm{~cm}$ high) were suspended from the inner sleeve with Chromel wires, to permit their easy removal and replacement (see Figure 1).

Incubation medium. The buffer solution used for in- cubation of the tissues was a modified Krebs bicarbonate buffer containing: $\mathrm{Na}, 146 ; \mathrm{K}, 5 ; \mathrm{Ca}, 2 ; \mathrm{Mg}, 1 ; \mathrm{Cl}, 114$; and $\mathrm{HCO}_{3}, 40 \mathrm{mEq}$ per $\mathrm{L}$. The buffer was equilibrated with 95 per cent $\mathrm{O}_{2}, 5$ per cent $\mathrm{CO}_{2}$ bubbled for 10 minutes through the solution, and incubated in the presence of a 95 per cent $\mathrm{O}_{2}, 5$ per cent $\mathrm{CO}_{2}$ atmosphere. Under these conditions the $\mathrm{pH}$ was approximately 7.4. In addition, gelatin (USP, obtained from J. T. Baker Chemicals Corporation, Phillisburg, N. J.), $200 \mathrm{mg}$ per $100 \mathrm{ml}$ (approximate), was routinely added and was easily dissolved by bringing the buffer solution to $38^{\circ} \mathrm{C}$. Glucose concentration (using glucose obtained from the National Bureau of Standards) was brought to $250 \mathrm{mg}$ per $100 \mathrm{ml}$ by the addition of dry glucose; $1.9 \mathrm{ml}$ of buffer thus contained $4.75 \mathrm{mg}$ of glucose.

Preparation of solution containing glucose-1-C $C^{14}$. For each batch of tracer glucose, $200 \mu \mathrm{c}$ of glucose-1-C ${ }^{14}$ (obtained from New England Nuclear Corporation and chromatographically pure) was dissolved in $50 \mathrm{ml}$ distilled water. Nonradioactive glucose was added to bring the final glucose concentration of this solution to $1,250 \mathrm{mg}$ per $100 \mathrm{ml} ; 0.1 \mathrm{ml}$ of the solution thus contained $0.4 \mu \mathrm{c}$ and $1.25 \mathrm{mg}$ of glucose.

Preparation of insulin standards. A single batch of insulin has been used throughout these investigations (Crystalline insulin, five times recrystallized, treated with trypsin, batch no. 466368, containing $26.6 \mathrm{U}$ per $\mathrm{mg}$ ). This preparation was made available to us through the courtesy of Dr. W. R. Kirtley of the Lilly Research Laboratories. Once monthly, a concentrated insulin standard was prepared from this crystalline material by dissolving $10 \mathrm{mg}$ in $10 \mathrm{ml}$ of distilled water, a few drops of $1.0 \mathrm{~N}$ hydrochloric acid being added until the solution was clear. This concentrated standard thus contained $26.6 \mathrm{U}$ per $\mathrm{ml}$. It was stored at $4^{\circ} \mathrm{C}$. Once weekly, $1 \mathrm{ml}$ of the concentrated standard was brought to $26.6 \mathrm{ml}$ with distilled water, a solution thus containing $1 \mathrm{U}$ per $\mathrm{ml}$. This working standard was again stored at $4^{\circ} \mathrm{C}$.

Each day, $1 \mathrm{ml}$ of the working standard was diluted to $100 \mathrm{ml}$ by the addition of buffer containing glucose and gelatin as described above. Two $\mathrm{ml}$ of this solution was diluted to $10 \mathrm{ml}$ with buffer containing glucose and gelatin. From this last solution serial dilutions were prepared using $10 \mathrm{ml}$ of insulin-containing solution and $10 \mathrm{ml}$ of buffer containing glucose and gelatin, resulting in solutions with $1,000,500,250,125,62$, and $31 \mu \mathrm{U}$ per $\mathrm{ml}$. During these dilution procedures, buffer containing glucose and gelatin was always poured first into any glassware used for the preparation of insulin standards, in order to moisten and coat the walls of the containers with the gelatin-containing buffer, so as to prevent loss of insulin upon glassware.

Assay technique: Principle. Rat adipose tissue is incubated in bicarbonate buffer with glucose-1- $\mathrm{C}^{14}$ for 2 hours. At the end of the incubation, the total $\mathrm{CO}_{2}$ present in the system is liberated by the addition of acid to the medium and is trapped in a small amount of $\mathrm{NaOH}$. The sodium carbonate so obtained is transferred to a planchet, dried, and its radioactivity determined. The total radioactivity of the $\mathrm{CO}_{2}$ is expected to be di- 
rectly proportional to the amount of the first carbon of glucose oxidized to $\mathrm{CO}_{2}$, and, as will be shown below, is further related to the amount of insulin present in the system.

Assay technique: Procedure. For each assay 18 flasks are used and into each was pipetted $1.9 \mathrm{ml}$ of unknown solution ${ }^{1}$ or of standard insulin solution in buffer containing glucose and gelatin as described above. Exactly $0.1 \mathrm{ml}$ of the glucose-1- $\mathrm{C}^{14}$ solution was then added to each flask, which thus contained $2 \mathrm{ml}$ of medium, $6 \mathrm{mg}$ glucose (i.e., $300 \mathrm{mg}$ per $100 \mathrm{ml}$ ) and $0.4 \mu \mathrm{c} \mathrm{C} \mathrm{C}^{14}$. The flasks were weighed to the nearest milligram and kept stoppered to prevent evaporation.

After the flasks had been prepared and weighed, three rats were successively killed by a blow to the head, decapitation and exsanguination. The abdomen was widely opened and the testes were displaced by gentle pressure from the scrotum into the abdominal cavity. Each testis in turn was lifted with forceps and the adipose tissue hanging from the epididymis was cut free (single cut) just distal to the epididymal vessels, where the base of the epididymal fat is somewhat narrower. Without chilling, and with a minimum of handling, each pad was then taken up at its base and further cut into three equal segments. ${ }^{2}$ As it was cut, each segment was dropped into its appropriate preweighed flask which had been kept stoppered. The segments were so distributed as to lead to the "balanced segment design" described below. The flasks were then rapidly reweighed to obtain the tissue weight. After gassing for 5 minutes with 95 per cent $\mathrm{O}_{2}, 5$ per cent $\mathrm{CO}_{2}$, using no. 21 hypodermic needles inserted through the rubber stoppers, the needles were withdrawn and the system was left airtight. The flasks were then incubated in a Dubnoff metabolic shaking incubator for 2 hours at $37^{\circ} \mathrm{C}$, using 72 shaking cycles per minute $(\mathrm{c} / \mathrm{min})$.

After incubation, $0.1 \mathrm{ml}$ of $1.8 \mathrm{~N} \mathrm{NaOH}$ freshly diluted with $\mathrm{CO}_{2}$-free water from saturated $\mathrm{NaOH}$ was injected into the suspended plastic cup and $0.2 \mathrm{ml}$ of $10 \mathrm{~N} \mathrm{H}_{2} \mathrm{SO}_{4}$ was added to the medium in each flask. Graduated tuberculin-type syringes fitted with no. 21 hypodermic needles were used for this procedure. The flasks were well mixed and agitated at $36 \mathrm{c} / \mathrm{min}$ for at least 60 minutes. The contents of each plastic cup were then transferred to a preweighed stainless steel planchet using two washes with 2 drops each of $\mathrm{CO}_{2}$-free water. To insure even drying each planchet also contained a disc of lens paper weighing approximately $1 \mathrm{mg}$. For this transfer, the plastic cups are best handled with rubber-covered curved forceps.

The planchets were then dried on a hot plate, with care to avoid boiling and splattering of the planchet contents.

1 For example, serum, glucose content having been brought to $250 \mathrm{mg}$ per $100 \mathrm{ml}$ by the addition of dry glucose.

2 The segment closest to the base (i.e., closest to the epididymis) is termed the "proximal" segment, followed by the "medial" and the "distal" segments. The proximal segment did not include the portion which had been handled with forceps.
After the contents appeared dry (approximately 0.5 hour), drying was continued for 1.5 hours at a somewhat higher setting of the plate. The planchets were cooled in a desiccator and reweighed. The radioactivity was estimated in a proportional flow counter. The counts ranged from several hundreds to several thousands per minute per planchet. The results are expressed as counts per minute per total $\mathrm{CO}_{2}$ produced per milligram of adipose tissue, self-absorption corrections being applied according to Karnovsky and associates (26).

\section{RESULTS}

\section{Evaluation of measurements and conditions}

Adequacy of $\mathrm{C}^{14} \mathrm{O}_{2}$ collection. In the experiments shown in Table I, a measured amount of $\mathrm{NaHC}^{14} \mathrm{O}_{3}$ was added to $2 \mathrm{ml}$ of either buffer or serum, $\mathrm{C}^{14} \mathrm{O}_{2}$. collection then being carried out as described above. Intervals of 30, 60 and $180 \mathrm{~min}-$ utes were allowed to elapse between the addition of acid to the buffer or serum, and the transfer of the alkali from cups to planchets. Furthermore, two normalities were used for the $0.1 \mathrm{ml} \mathrm{NaOH}$ contained in the cup : 1.8 and 0.9 normal. Theoretically, the normality required to neutralize the carbonic acid formed would be between 0.6 and 0.8 for the $0.1 \mathrm{ml}$ volume used. The results obtained indicate that the recovery of $\mathrm{C}^{14} \mathrm{O}_{2}$ was maximal from 30 minutes on, although this was true only when the $\mathrm{NaOH}$ added to the cup was $1.8 \mathrm{~N}$, and that comparable recoveries were obtained from buffer and from serum. It is necessary to stress the need for heating the $\mathrm{CO}_{2}$-containing alkali on the planchets, a need probably explainable on the basis of the hygroscopy of the excess $\mathrm{NaOH}$. Furthermore, complete drying on the hot plate

TABLE I

Recovery as $\mathrm{C}^{14} \mathrm{O}_{2}$ of $\mathrm{NaHC}^{14} \mathrm{O}_{3}$ added to buffer or serum

\begin{tabular}{ccccc}
\hline \hline Medium & $\begin{array}{c}\text { Collec- } \\
\text { tion } \\
\text { period }\end{array}$ & $\begin{array}{c}\text { NaOH } \\
\text { (normal- } \\
\text { ity) }\end{array}$ & $\begin{array}{c}\text { Weight } \\
\text { on } \\
\text { planchets }\end{array}$ & $\begin{array}{c}\text { Total } \\
\text { cpm* }\end{array}$ \\
\hline Buffer & $\begin{array}{c}\text { min } \\
30\end{array}$ & 1.8 & 11.8 & 859 \\
Serum & 30 & 1.8 & 11.4 & 841 \\
Buffer & 60 & 1.8 & 11.1 & 813 \\
Serum & 60 & 1.8 & 11.5 & 870 \\
Buffer & 180 & 1.8 & 11.5 & 855 \\
Serum & 180 & 1.8 & 11.6 & 810 \\
Buffer & 180 & 0.9 & 5.9 & 606 \\
Serum & 180 & 0.9 & 5.8 & 614 \\
\hline
\end{tabular}

${ }^{*}$ Each figure represents the mean of two experiments. 


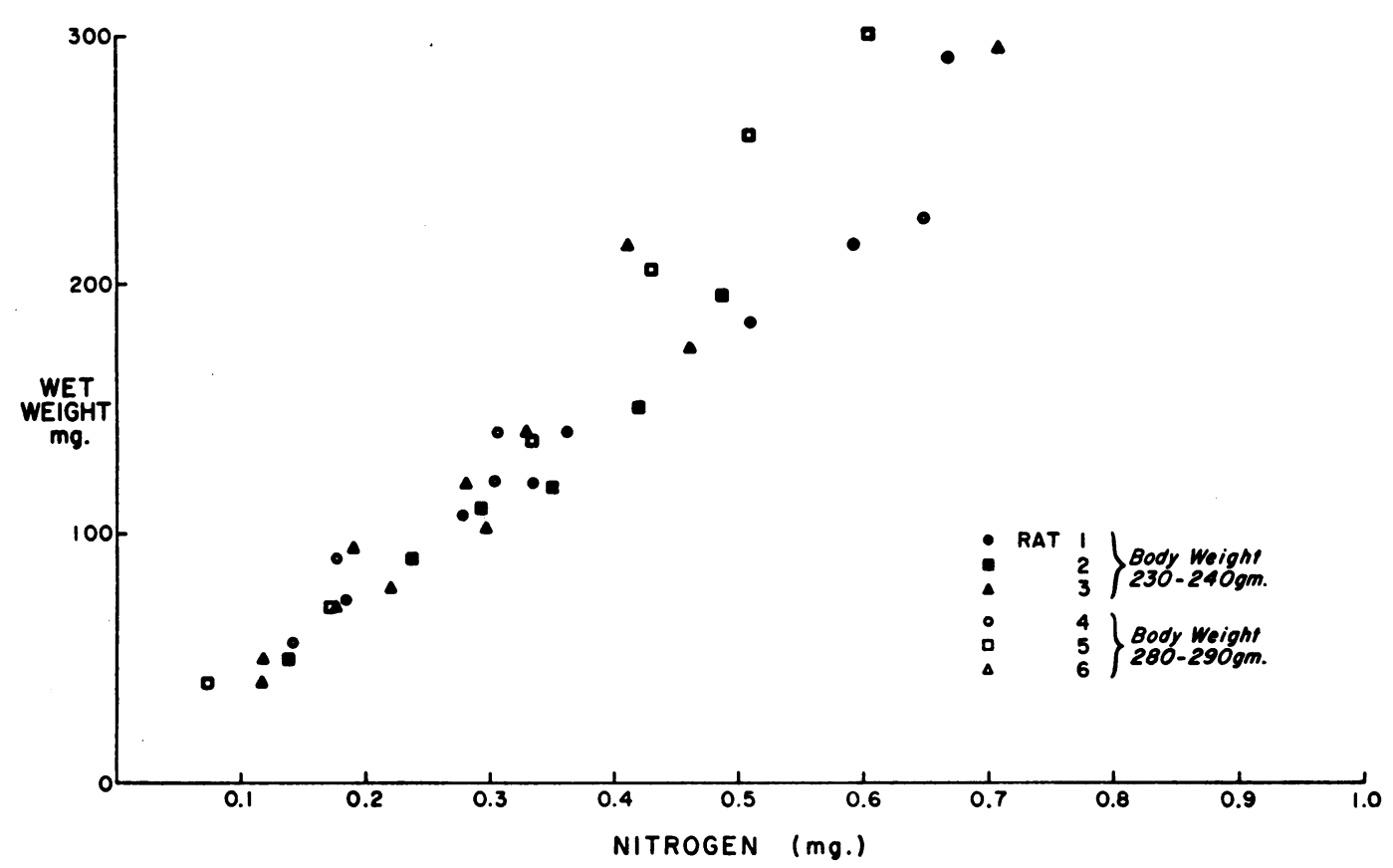

Fig. 2. Relation of wet weight of adipose tissue segments to their nitrogen content.

insures even weights and decreases the importance of accepting the validity of the correction factor used to correct for self-absorption in calculating the radioactivity contained in the sample.

Reference measurement. Reference measurements which might be considered in this tissue are primarily wet weight, dry fat-free weight, or nitrogen. Dry fat-free weight of fragments of tissue of the size used averaged between 1 and $2 \mathrm{mg}$, a range inconvenient for accurate measurement. Wet weight and total nitrogen content have been compared in a large series of experiments of which six are shown in Figure 2. Although the ratio of nitrogen to wet weight varies from animal to animal, it is apparent from the figure that it remains relatively constant within tissues obtained from $a$ single animal. It would seem, therefore, that wet weight of adipose tissue permits reasonable quantitation of the active tissue components contained in each fragment.

Duration of the incubation. Winegrad and Renold (13) have shown that rat adipose tissue incubated either with or without insulin for periods varying from 15 minutes to 6 hours metabolizes glucose to $\mathrm{CO}_{2}$ at approximately the same rate for the first 3 hours with some decrease after that time. Using net gas formation in the presence of glucose, Ball and co-workers (18) reported constant activity of the tissue up to 6 hours. Piazza, Goodner and Freinkel (27) have recently reported that adipose tissue releases trichloroacetic acid-soluble $\mathrm{I}^{131}$ when incubated with insulin labeled with $I^{131}$, although to a lesser extent than is true for diaphragm. Whereas the activity studies just mentioned do not suggest a significant destruction of insulin-like activity for periods of incubation up to 3 hours, it is evident that this possibility must be considered in each instance.

Ionic environment. Zahnd, Dagenais and Renold $^{3}$ have studied in detail the ionic requirements both for baseline activity of rat adipose tissue and for the insulin response, and found that the baseline activity of the tissue is quite markedly affected by variations in both the cationic and the anionic environment. Lack of potassium, magnesium and calcium resulted in increased baseline activity, while the level of activity reached in the presence of insulin was somewhat depressed. As a result, the insulin effect was considerably smaller. Baseline activity, insulin-stimulated activity, and insulin effect all were much smaller when phosphate was substituted for bicarbonate. No variation in the ionic environment has yet been found which leads to an increased insulin effect, and use

3 Unpublished observations. 
of the Krebs bicarbonate buffer which we have adopted appears, for the present, optimal. Hagen, Ball and Cooper (28), using net gas production as an index of tissue activity, came to similar conclusions.

Concentration of glucose. Jeanrenaud and Renold (22) have studied in some detail the interrelations of the effects of glucose concentration and insulin concentration upon rat adipose tissue. For any given dose of insulin a greater response was obtained when the concentration of glucose was greater, the response being roughly proportional to the logarithm of the glucose concentration. Accordingly, the relatively high glucose concentration of $300 \mathrm{mg}$ per $100 \mathrm{ml}$ has been selected for the procedure reported here. The primary point is to keep glucose concentration constant in any individual assay. Whenever a sample with a glucose concentration higher than $300 \mathrm{mg}$ per $100 \mathrm{ml}$ was assayed, the glucose concentration for both the standards and all unknowns was similarly increased.

The addition of gelatin. The routine addition of gelatin to all solutions used in these studies has been prompted by the need to avoid loss of insulin on glassware, a loss which has been well documented at extremely low concentrations $(29,30)$, and which we have confirmed.

Weight of animals. Ball and associates (18) have demonstrated a rather striking relationship between the weight of animals and the net gas formation by their adipose tissue. As marked a relationship has not been observed when $\mathrm{C}^{14} \mathrm{O}_{2}$ production from glucose-1-C ${ }^{14}$ was the metabolic index. It seemed, however, that tissues were more frequently below average activity when animal weights of $260 \mathrm{~g}$ were exceeded, and greater than usual fluctuations in activity were observed in animals weighing less than $200 \mathrm{~g}$. Furthermore, when animals weighing less than $220 \mathrm{~g}$ were used, it was frequently impossible to obtain sufficient tissue to remain within the optimal weight range for each fragment. Accordingly, for the animals of the particular strain used, a weight range of 220 to $260 \mathrm{~g}$ is suggested. It is conceivable that limitation to a smaller weight range would be advantageous, although this causes practical difficulties.

Weight of tissue fragments. When the activity was expressed in counts per minute per milligram of tissue, analysis of well over 600 individual ob- servations indicated that the variation of activity of segments weighing between 70 and $170 \mathrm{mg}$ was similar and did not show a trend relating it to segment weight. Below $70 \mathrm{mg}$, activity expressed per milligram of tissue tended to be higher, and above $170 \mathrm{mg}$, it tended to be lower than between these two values. Accordingly, it is suggested that tissue fragments be kept within this general weight range.

Differences between segments and adequacy of routine procedures such as pipetting. The basic experimental unit used in all assays is a segment (approximately one-third) of each epididymal fat pad. To determine whether systematic differences exist between the responses observed in the different parts of each fat pad, i.e., in the distal, medial and proximal segments (see Footnote 2), an experiment was performed using 12 rats, three on each of four successive days. On the first and third days, all the segments from one fat pad of each rat were incubated with buffer only and those from the other pad with $62 \mu \mathrm{U}$ per $\mathrm{ml}$ of standard insulin. On the intervening days, the treatments were buffer and $1000 \mu \mathrm{U}$ per $\mathrm{ml}$ of insulin. The differences between the geometric means of the counts per minute per milligram were evaluated by an analysis of variance (31) of the log counts per minute. On three days out of the four, differences between individual rats were significantly $(p<0.001)$ greater than the residual error term.

TABLE II

Response of epididymal fat pads of rats by segment*

\begin{tabular}{|c|c|c|c|c|}
\hline \multirow{2}{*}{$\begin{array}{l}\text { Experi- } \\
\text { ment } \\
\text { day }\end{array}$} & \multirow[b]{2}{*}{$\begin{array}{c}\text { Insulin } \\
\text { dose }\end{array}$} & \multicolumn{3}{|c|}{ Geometric mean } \\
\hline & & $\begin{array}{c}\text { Distal } \\
\text { segment }\end{array}$ & $\begin{array}{c}\text { Medial } \\
\text { segment }\end{array}$ & $\begin{array}{l}\text { Proximal } \\
\text { segment }\end{array}$ \\
\hline $\begin{array}{l}1 \\
3 \\
\text { Mean }\end{array}$ & $\begin{array}{r}\mu U \\
0 \\
0\end{array}$ & $\begin{array}{c}c p m / m g \\
5.6 \\
6.9 \\
6.2\end{array}$ & $\begin{array}{c}c p m / m g \\
6.8 \\
6.0 \\
6.4\end{array}$ & $\begin{array}{c}c p m / m g \\
5.8 \\
5.4 \\
5.6\end{array}$ \\
\hline${ }_{\text {Mean }}^{1}$ & $\begin{array}{l}62 \\
62\end{array}$ & $\begin{array}{l}15.6 \\
16.6 \\
16.1\end{array}$ & $\begin{array}{l}12.8 \\
13.4 \\
13.1\end{array}$ & $\begin{array}{r}8.9 \\
12.6 \\
10.6\end{array}$ \\
\hline $\begin{array}{l}2 \\
4 \\
\text { Mean }\end{array}$ & $\begin{array}{l}0 \\
0\end{array}$ & $\begin{array}{l}4.5 \\
4.3 \\
4.4\end{array}$ & $\begin{array}{l}5.9 \\
5.1 \\
5.5\end{array}$ & $\begin{array}{l}4.4 \\
4.7 \\
4.6\end{array}$ \\
\hline $\begin{array}{l}2 \\
4 \\
\text { Mean }\end{array}$ & $\begin{array}{l}1,000 \\
1,000\end{array}$ & $\begin{array}{l}16.7 \\
26.8 \\
21.2\end{array}$ & $\begin{array}{l}18.5 \\
26.6 \\
22.2\end{array}$ & $\begin{array}{l}16.0 \\
24.3 \\
19.7\end{array}$ \\
\hline
\end{tabular}

* Each value is derived from the corresponding segments from thrẹe rats. 
TABLE III

Experiment to compare adipose tissue segments, preparation of insulin solutions $(A$ and $B)$, and order of pipetting $(1,2,3)$ *

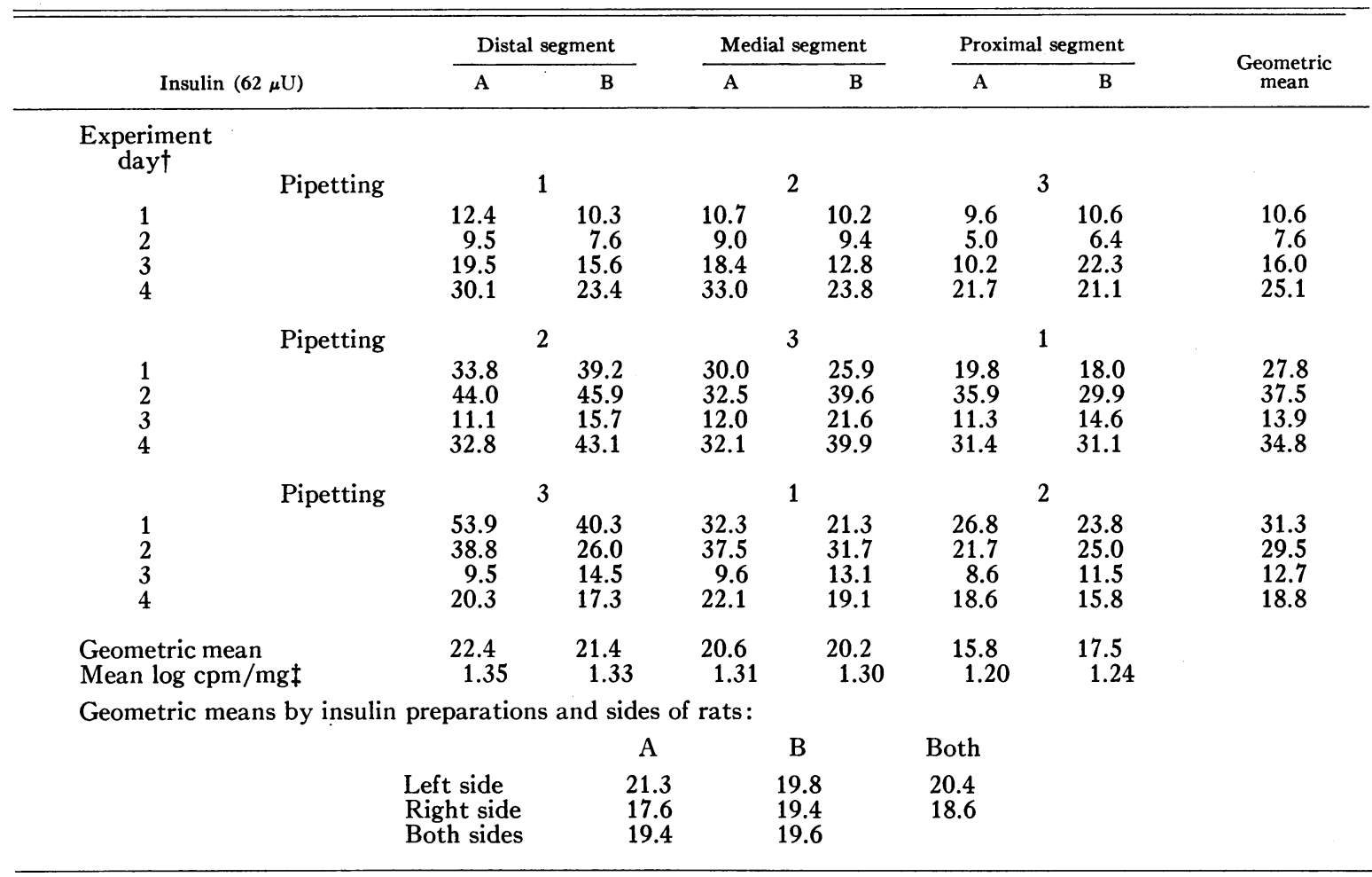

* Each line represents the responses, in cpm per $\mathrm{mg}$, from one rat.

$\dagger$ On Days 1 and 2, insulin preparation A was used for segments from the left side of the rat and preparation B for segments from the right side. This assignment was reversed on Days 3 and 4 .

$\ddagger$ Standard error of each mean was 0.034 , as calculated with the treatment $X$ day interaction as error term.

Segment differences (Table II) were less pronounced, but the combined responses from the proximal segments were significantly lower ( $p$ $<0.01)$ than from the other segments. The differences between the medial and distal segments were inconsistent and were significant $(p<0.05)$ on one day only.

Again with the use of three rats on each of four successive days, a factorial experiment (31) was performed to study the effects of : $a$ ) segment differences as indicated by the results just reported; b) variability in the preparation of the standard insulin solution; $c$ ) repeated use of the same pipet for any one solution; and $d$ ) differences between right and left fat pads of the same rats. Two preparations of insulin (A and B) were made by independent serial dilutions starting from the same standard solution containing $26 \mathrm{U}$ per $\mathrm{ml}$. Each piece of tissue was incubated with $62 \mu \mathrm{U}$ of insulin taken from either preparation A or preparation B.
The order of pipettings was designated as 1,2 or 3 , the order being balanced over all segments on any one day.

As shown in Table III, the proximal segments were again found to yield significantly $(p<0.01)$ lower values than the other segments; differences between rats were also highly significant ( $p$ $<0.001)$. On the other hand, no significant effect of insulin preparation, sides, or pipettings was observed. These results led to the adoption of the "balanced segment design" discussed in the following paper.

\section{Sensitivity}

\section{DISCUSSION}

That insulin concentrations as low as $10 \mu \mathrm{U}$ per $\mathrm{ml}$, in the presence of gelatin-containing buffer, significantly enhance the production of $\mathrm{C}^{14} \mathrm{O}_{2}$ from glucose-1- $\mathrm{C}^{14}$ by the tissue preparation used is shown in Table IV. 
Relationship between dose and response and choice of a statistical response metameter

Dose-response relationships observed in six animals are shown in Figure 3. Although the data are obtained as total counts per minute per milligram wet weight (Figure 3A), it is desirable that they be transferred into some other units to meet the following requirements $(32): a$ ) similar absolute biological and experimental variation at different response levels as measured by the "variance" or square of the standard deviation (this requirement is referred to in statistical terms as "homoscedasticity"); $b$ ) an additive, linear response to increasing doses of insulin within a suitable range.

Analyses were made of the square roots of the counts per minute per milligram and of the logarithms of the counts per minute per milligram to see whether or not these "metameters" gave satisfactory results. As illustrated by the examples in Figure 3, the requirement of linearity was met reasonably well with each of these metameters in the analysis of a number of dose-response curves. While the square root responses (Figure 3B) exhibited greater scatter at high concentrations of insulin than at low concentrations, this difficulty was avoided when the log counts per minute (Figure 3C) were used. To provide a further
TABLE IV

Effect of $10 \mu U$ insulin per ml gelatin-containing medium upon the oxidation of glucose-1-C ${ }^{14}$ to $\mathrm{C}^{14} \mathrm{O}_{2}{ }^{*}$

\begin{tabular}{|c|c|c|c|}
\hline \multirow[b]{2}{*}{ Animal no. } & \multicolumn{3}{|c|}{ Radioactivity of $\mathrm{CO}_{2}$ produced } \\
\hline & $\begin{array}{c}\text { A(without } \\
\text { insulin) }\end{array}$ & $\begin{array}{l}\text { B(with } \\
\text { insulin) }\end{array}$ & Ratio B/A \\
\hline \multirow{4}{*}{1} & $\mathrm{cpm} / \mathrm{mg}$ & $\mathrm{cpm} / \mathrm{mg}$ & \\
\hline & 0.19 & 0.32 & 1.68 \\
\hline & 0.18 & 0.30 & 1.67 \\
\hline & 0.22 & 0.24 & 1.09 \\
\hline \multirow[t]{3}{*}{2} & 14.1 & 16.0 & 1.14 \\
\hline & 13.8 & 18.0 & 1.30 \\
\hline & 15.5 & 20.0 & 1.29 \\
\hline \multirow[t]{3}{*}{3} & 9.2 & 12.9 & 1.40 \\
\hline & 10.4 & 12.1 & 1.16 \\
\hline & 11.1 & 15.5 & 1.40 \\
\hline \multirow[t]{2}{*}{4} & 12.8 & 14.9 & 1.16 \\
\hline & 12.7 & 17.8 & 1.40 \\
\hline \multirow[t]{2}{*}{5} & 7.62 & 10.1 & 1.33 \\
\hline & 8.15 & 10.3 & 1.26 \\
\hline 6 & 19.1 & 22.4 & 1.17 \\
\hline 7 & 2.80 & 3.66 & 1.31 \\
\hline 8 & 1.40 & 2.31 & 1.65 \\
\hline 9 & 3.59 & 8.81 & 2.45 \\
\hline 10 & 14.8 & 18.8 & 1.27 \\
\hline 11 & 25.5 & 28.2 & 1.11 \\
\hline 12 & 5.93 & 8.01 & 1.35 \\
\hline Mean & & & 1.38 \\
\hline SE & & & 0.08 \\
\hline Significance & & & $\mathrm{p} \dagger<0.01$ \\
\hline
\end{tabular}

* Comparison 'was between matched segments from right and left epididymal pads.

$\dagger$ Probability that observed ratio could be a random sample from a population with a true ratio of 1.00 .
A

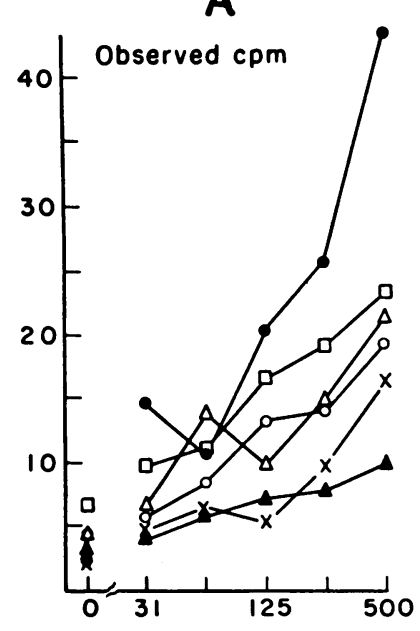

B

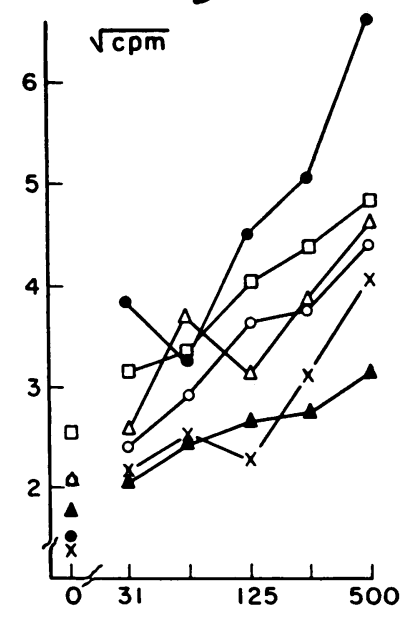

ADDED INSULIN, $\mu U$ per $\mathrm{mI}$.

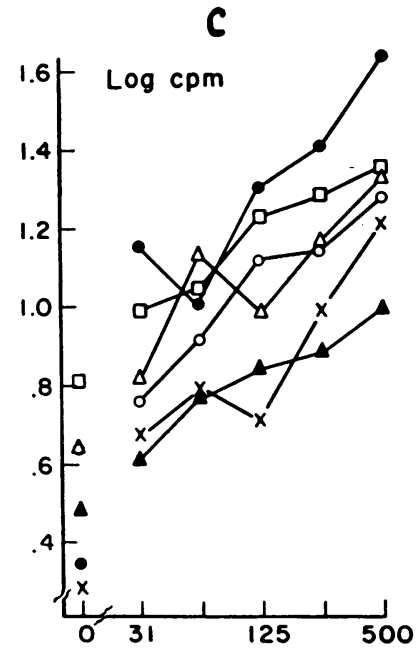

500

Fig. 3. Dose-Response curves obtained in six animals Plotted With three different RESPONSE METAMETERS. The responses are expressed per milligram wet weight of tissue. The doses of insulin are plotted on a logarithmic scale. 
TABLE V

Effect of purified human albumin * and $\gamma$-globulin * on the oxidation of glucose-1-C $C^{14}$ by rat adipose tissue

\begin{tabular}{lcc}
\hline \hline & $\begin{array}{c}\text { Radio- } \\
\text { activity } \\
\text { of CO2 } \\
\text { produced }\end{array}$ \\
\hline & $\begin{array}{c}\text { No. of } \\
\text { values }\end{array}$ & $\begin{array}{c}\text { cpm/mg } \\
\text { Insulin }(31 \mu \mathrm{U} / \mathrm{ml})\end{array}$ \\
Human albumin $(40 \mathrm{mg} / \mathrm{ml})$ & $6 \dagger$ & 7.58 \\
Human $\gamma$-globulin $(10 \mathrm{mg} / \mathrm{ml})$ & $12 \dagger$ & 5.92 \\
Insulin $(1,000 \mu \mathrm{U} / \mathrm{ml})$ & 6 & 36.99 \\
& & 36.08
\end{tabular}

* Obtained from the Protein Foundation, Jamaica Plain Mass., through the courtesy of Dr. Robert B. Pennell and Dr. H. N. Antoniades. Dialyzed against bicarbonate buffer prior to use.

$\dagger$ In each of six rats, single high and low insulin standards were compared with duplicate samples of albumin and globulin.

comparison, the index of precision $(\lambda=\mathrm{s} / \mathrm{b})$ for other assays was calculated with both metameters. The logarithmic transformation resulted in lower values of $\lambda$ for 13 of 18 assays. The consistency from assay to assay was compared by calculating the standard deviations of the observed values of $s$ (standard deviation) and of $b$ (slope of the line). The logarithmic analyses resulted in somewhat smaller coefficients of variation $(37$, against 65 per cent for s, 34 against 37 per cent for b). The logarithmic transformation was therefore chosen as the routine method for subsequent analyses.

\section{Specificity}

That the effects of insulin upon adipose tissue are not completely specific is an a priori assumption of these studies. Just as many agents affect blood glucose levels in the intact animal, or glucose uptake by the isolated hemidiaphragm, many agents are likely to affect glucose metabolism by adipose tissue. The information to be presented in this section is intended merely to outline the general area of the specificity problem.

Since insulin is a protein, it seemed of interest to document whether proteins in general accelerate glucose oxidation by isolated adipose tissue. Table $\mathrm{V}$ demonstrates that purified human albumin or $\gamma$-globulin exerted less insulin-like action upon this tissue than the low standard ( $31 \mu \mathrm{U}$ per $\mathrm{ml})$, even at concentrations approximating those of serum or plasma. It is important to point out here that commercial preparations of these and other proteins frequently contain relatively large amounts of the agents used during their isolation, and that adequate dialysis is required prior to their use in the presence of isolated tissues.

The effects of glutathione are shown in Table VI. In the disulfide form, this peptide did not influence the oxidation of the first glucose carbon by adipose tissue, nor did it affect the action of added insulin. In the sulfhydryl form, however, glutathione alone, at the relatively high concentra-

TABLE VI

Effect of oxidized and reduced glutathione $(20 \mathrm{mM})$ on the formation of $\mathrm{C}^{14} \mathrm{O}_{2}$ from glucose-1-C $C^{14}$ by rat adipose tissue, with and without added insulin $(250 \mu \mathrm{U}$ per $\mathrm{ml})$ *

\begin{tabular}{|c|c|c|c|c|c|c|}
\hline $\begin{array}{c}\text { Animal } \\
\text { no. }\end{array}$ & $\begin{array}{l}\text { No } \\
\text { addition }\end{array}$ & $\begin{array}{c}\text { Glutathione } \\
\text { (oxidized) }\end{array}$ & $\begin{array}{c}\text { Glutathione } \\
\text { (reduced) }\end{array}$ & Insulin & $\begin{array}{l}\text { Insulin and } \\
\text { glutathione } \\
\text { (oxidized) }\end{array}$ & $\begin{array}{l}\text { Insulin and } \\
\text { glutathione } \\
\text { (reduced) }\end{array}$ \\
\hline $\begin{array}{l}1 \\
2 \\
3 \\
4 \\
5\end{array}$ & $\begin{array}{l}3.61 \dagger \\
5.07 \\
4.57 \\
5.62 \\
9.16\end{array}$ & $\begin{array}{l}5.39 \\
4.71 \\
5.82 \\
8.05 \\
6.23\end{array}$ & & $\begin{array}{l}39.55 \\
28.26 \\
31.07 \\
51.65 \\
27.44\end{array}$ & $\begin{array}{l}23.08 \\
49.80 \\
28.66 \\
36.55 \\
28.61\end{array}$ & \\
\hline Mean & 5.61 & 6.04 & & 35.59 & 33.34 & \\
\hline $\begin{array}{r}6 \\
7 \\
8 \\
9 \\
10 \\
11\end{array}$ & $\begin{array}{l}5.21 \\
6.00 \\
5.05 \\
3.59 \\
4.10 \\
5.50\end{array}$ & & $\begin{array}{r}16.57 \\
12.50 \\
10.86 \\
8.60 \\
10.70 \\
8.80\end{array}$ & $\begin{array}{l}60.20 \\
42.93 \\
22.86 \\
14.70 \\
13.20 \\
12.10\end{array}$ & & $\begin{array}{r}15.48 \\
15.68 \\
10.31 \\
8.10 \\
10.00 \\
9.30\end{array}$ \\
\hline Mean & 4.91 & & 11.34 & 27.68 & & 11.48 \\
\hline
\end{tabular}

* Glutathione, with or without insulin, was added to the buffer 2 hours prior to the addition of adipose tissue, and kept at room temperature during that time. The samples not containing glutathione were treated identically.

$\dagger$ Radioactivity of $\mathrm{CO}_{2}$ produced $(\mathrm{cpm} / \mathrm{mg})$. 
TABLE VII

Effect of serum $(0.1 \mathrm{ml}$ per $\mathrm{ml})$ from normal guinea pigs and from guinea pigs immunized with beef insulin upon the formation of $\mathrm{C}^{14} \mathrm{O}_{2}$ from glucose-1-C $C^{14}$ by rat adipose tissue, with and without added insulin (250 $\mathrm{HU}$ per $\mathrm{ml}$ )

\begin{tabular}{|c|c|c|c|c|c|c|}
\hline $\begin{array}{c}\text { Animal } \\
\text { no. }\end{array}$ & $\begin{array}{l}\text { No } \\
\text { addition }\end{array}$ & $\begin{array}{l}\text { Normal } \\
\text { serum }\end{array}$ & $\begin{array}{l}\text { Anti-insulin } \\
\text { serum }\end{array}$ & Insulin & $\begin{array}{c}\text { Insulin and } \\
\text { normal serum }\end{array}$ & $\begin{array}{l}\text { Insulin and } \\
\text { antiserum }\end{array}$ \\
\hline $\begin{array}{l}1 \\
2 \\
3 \\
4 \\
5 \\
6\end{array}$ & $\begin{array}{l}2.85^{*} \\
3.39 \\
3.98\end{array}$ & & $\begin{array}{r}23.02 \\
12.49 \\
10.49 \\
6.76 \\
12.48 \\
10.12\end{array}$ & $\begin{array}{l}64.84 \\
48.96 \\
26.91 \\
18.10 \\
36.06 \\
27.65\end{array}$ & & $\begin{array}{r}15.39 \\
14.24 \\
6.52 \\
6.25 \\
12.51 \\
8.49\end{array}$ \\
\hline Mean & 3.41 & & 12.56 & 37.09 & & 10.56 \\
\hline $\begin{array}{l}7 \\
8 \\
9\end{array}$ & $\begin{array}{l}4.02 \\
3.94 \\
3.99\end{array}$ & $\begin{array}{l}31.06 \\
10.84 \\
15.16\end{array}$ & & $\begin{array}{l}51.88 \\
28.22 \\
21.81\end{array}$ & $\begin{array}{l}44.29 \\
32.31 \\
33.31\end{array}$ & \\
\hline Mean & 3.98 & 19.02 & & 30.64 & 36.64 & \\
\hline
\end{tabular}

* Radioactivity of $\mathrm{CO}_{2}$ produced $(\mathrm{cpm} / \mathrm{mg})$.

tion used, had an "insulin-like" effect, while completely neutralizing the effect of added insulin. The latter observation is in keeping with the known insulin-inactivating effect of reduced glutathione and of cysteine. The stimulating effect of glutathione alone is as yet unexplained. The suggestion that certain amino acids and peptides alter lipogenesis from acetate by adipose tissue (33), a metabolic event likely to be associated with altered rates of oxidation of the first glucose carbon, is but one of several possible explanations, all hypothetical.

The effects of reduced glutathione upon this tissue were studied in part because of its possible usefulness in the characterization of insulin-like substances in complex solutions. The experiments shown in Table VII were similarly motivated. Anti-insulin serum ${ }^{4}$ was obtained by immunizing guinea pigs against beef insulin according to the procedure described by Moloney and Coval (34). It is evident from the data that $0.1 \mathrm{ml}$ of the antiserum per $\mathrm{ml}$ of medium exerted a small but significant "insulin-like" effect upon adipose tissue (presumably endogenous insulin-like activity of guinea pig serum) while completely neutralizing the activity of $250 \mu \mathrm{U}$ added beef insulin.

It is of importance to consider whether hormones other than insulin exert "insulin-like" or "anti-insulin-like" effects upon the adipose tissue

4 The anti-insulin serum used in these experiments was generously made available to us by Drs. Werner Creutzfeldt and Paul Lacy, St. Louis, Mo. preparation used. Present information available to us may be summarized as follows. Epinephrine markedly affects adipose tissue metabolism in general and, in particular, stimulates glucose uptake, glucose oxidation, and glyceride-glycerol synthesis by this tissue. However, glucose oxidation by the phosphogluconate-oxidative pathway, as well as lipogenesis, remains relatively unaffected $(24,35)$. As a result, the oxidation of the first carbon of glucose is little affected by epinephrine, at least at physiological concentrations of the hormone, as shown in Table VIII. This contrasts with the well documented antagonistic effect of epinephrine in the rat hemidiaphragm assay (36). Growth hormone $(25,37)$ and adrenocorticotropin (3739) have been reported to influence glucose metab-

TABLE VIII

Effect of physiological concentrations of epinephrine upon the formation of $\mathrm{C}^{14} \mathrm{O}_{2}$ from glucose-1-C $C^{14}$ by rat adipose tissue, with and without added insulin $(250 \mu \mathrm{U}$ per $\mathrm{ml})$.

\begin{tabular}{lcccc}
\hline & \multicolumn{3}{c}{ Animal no. } & \\
\cline { 2 - 4 } Treatment & 1 & 2 & 3 & Mean \\
\hline No addition & $2.93^{*}$ & 4.02 & 2.94 & 3.30 \\
Epinephrine & & & & \\
$1.8 \mu \mathrm{g} / \mathrm{L}$ & 4.98 & 4.63 & 2.35 & 3.99 \\
$18 \mu \mathrm{g} / \mathrm{L}$ & 3.96 & 4.42 & 2.97 & 3.78 \\
Insulin & 12.49 & 23.94 & 7.63 & 14.69 \\
$\begin{array}{l}\text { Insulin + epinephrine } \\
1.8 \mu \mathrm{g} / \mathrm{L} \\
18 \quad 1.92\end{array}$ & 21.81 & 7.09 & 13.61 \\
$18 \mathrm{~g} / \mathrm{L}$ & 14.97 & 19.04 & 9.85 & 14.62 \\
\hline
\end{tabular}

* Radioactivity of $\mathrm{CO}_{2}$ produced (cpm/mg). 
olism by rat adipose tissue in vitro in a manner similar to that of epinephrine. Again, however, an insulin-like effect of these hormones appears unlikely under physiological conditions, in view of the concentrations required. Human growth hormone, in the concentration range of 0.1 to $5.0 \mu \mathrm{g}$ per $\mathrm{ml}$, and $\mathrm{ACTH}$ in the concentration range of 0.1 to $100 \mathrm{mU}$ per $100 \mathrm{cc}$ do not effect the oxidation of the first carbon of glucose by this tissue, either by itself or in combination with insulin. ${ }^{5}$ The insulin-like effects of glucagon upon adipose tissue are markedly diminished by pretreatment with cysteine, suggesting that they are at least in part attributable to contamination with insulin (40). Prolactin has been shown to affect adipose tissue metabolism in a manner similar to that of insulin $(27,41)$, although at concentrations which are several orders of magnitude greater than those required for insulin. Glucocorticoid effects upon glucose metabolism by adipose tissue have been sought, but not found by us (42) although contrary observations have been reported very recently (43-45).

The authors suggest that the information so far available has failed to reveal hormonal activity other than that of insulin which is likely to interfere significantly with the determination of ILA in samples containing physiological amounts of these activities, while recognizing the limitation of this argument. On the other hand, the studies which have been mentioned, as well as others, clearly indicate that adipose tissue is a tissue whose metabolic balance is delicately controlled by a number of agents, including hormones. Another example concerns the reported ILA of nicotinic acid at concentrations which may occur in blood during therapy with this agent (40). It seems evident that whenever "insulin-like" activity, as defined in this report, is found in complex biological samples, a great deal of additional evidence will be required before identity of this activity with insulin can be assumed.

\section{SUMMARY}

A bioassay procedure suitable for measuring small quantities of insulin or "insulin-like activity"

\footnotetext{
5 Steinke, J., Zahnd, G., and Renold, A. E. Unpublished observations reported to 42nd annual meeting of the Endocrine Society, Miami, June, 1960, page 58 of program.
}

has been presented. The procedure is based upon the responsiveness to insulin of isolated epididymal rat adipose tissue. Several indices of insulin-like activity may be used, including glucose uptake, net gas formation, and lipogenesis from glucose labeled with $\mathrm{C}^{14}$. The index selected has been that of production of $\mathrm{C}^{14} \mathrm{O}_{2}$ from glucose-1- $\mathrm{C}^{14}$.

The method is capable of detecting $10 \mu \mathrm{U}$ of insulin per $\mathrm{ml}$. The relationship between the logarithm of the insulin concentration and the logarithm of the response appears to be linear and is analyzed further in the subsequent paper. An advantage of the procedure derives from the ability to compare several standard solutions and unknown samples within tissue from any one animal. It is sufficiently convenient to allow for the routine comparison of two standards and four unknown samples in each of three rats on any given day.

The effect of beef insulin upon this tissue is inhibited by pretreatment with reduced glutathione or by addition of antiserum obtained from guinea pigs. Although the tissue is responsive to many metabolic agents, including those of endocrine origin, information available so far has failed to reveal hormonal activities other than those of insulin which are likely to interfere significantly with the determination of insulin-like activity in samples containing physiological concentrations of these activities. It is essential, however, to consider any measured activity other than that derived from added crystalline insulin as "insulin-like" until sufficient evidence can be produced to establish its identity with insulin.

\section{REFERENCES}

1. Bornstein, J. A technique for the assay of small quantities of insulin using alloxan diabetic hypophysectomized, adrenalectomized rats. Aust. J. exp. Biol. med. Sci. 1950, 28, 87.

2. Anderson, E., Wherry, F., Bates, R. W., and Cornfield, J. A method for assay of insulin using alloxan diabetic hypophysectomized mouse. Proc. Soc. exp. Biol. (N. Y.) 1957, 94, 321.

3. Beigelman, P. M. Insulin biosassays in vivo in Hormones in Human Plasma, H. N. Antoniades, Ed. Boston, Little, Brown, 1960.

4. Balmain, J. H., Cox, C. P., Folley, S. J., and McNaught, M. L. Bioassay of insulin in vitro by manometric measurements on slices of mammary glands. J. Endocr. 1954, 11, 269.

5. Groen, J., Kamminga, C. E., Willebrands, A. F., and Blickman, J. R. Evidence for the presence of in- 
sulin in blood serum. A method for an approximate determination of the insulin content of blood. J. clin. Invest. 1952, 31, 97.

6. Vallance-Owen, J. and Hurlock, B. Estimation of plasma-insulin by the rat diaphragm method. Lancet 1954, 1, 68.

7. Vallance-Owen, J., Hurlock, B., and Please, N. W. Estimation of plasma-insulin. Lancet 1954, 1, 983.

8. Takeuchi, S., Ohashi, S., and Kobayashi, Y. Quantitative assay of insulin in blood plasma in normal and alloxanized dogs by rat diaphragm method. J. Pharmacol. exp. Ther. 1957, 119, 436.

9. Oyama, J., and Grant, R. L. Insulin activity of serum by the mouse-diaphragm technique. Fed. Proc. 1959, 18, 297.

10. Willebrands, A. F., and Groen, J. Insulin bioassays in vitro: Using isolated rat diaphragm in Hormones in Human Plasma, H. N. Antoniades, Ed. Boston, Little, Brown, 1960.

11. Krahl, M. E. The effect of insulin and pituitary hormones on glucose uptake in muscle. Ann. N. Y. Acad. Sci. 1951, 54, 649.

12. Haugaard, N., and Marsh, J. B. Effect of insulin on the metabolism of adipose tissue from normal rats. J. biol. Chem. 1952, 194, 33.

13. Winegrad, A. I., and Renold, A. E. Studies on rat adipose tissue in vitro. I. Effects of insulin on the metabolism of glucose, pyruvate, and acetate. J. biol. Chem. 1958, 233, 267.

14. Renold, A. E., Winegrad, A. I., and Martin, D. B. Diabète sucré et tissu adipeux. Helv. med. Acta 1957, 24, 322.

15. Martin, D. B., Renold, A. E., and Dagenais, Y. M. An assay for insulin-like activity using rat adipose tissue. Lancet 1958, 2, 76.

16. Cahill, G. F., Jr., Leboeuf, B., and Renold, A. E. Studies on rat adipose tissue in vitro. III. Synthesis of glycogen and glyceride-glycerol. J. biol. Chem. 1959, 234, 2540.

17. Winegrad, A. I., and Renold, A. E. Studies on rat adipose tissue in vitro. II. Effects of insulin on the metabolism of specifically labeled glucose. J. biol. Chem. 1958, 233, 273.

18. Ball, E. G., Martin, D. B., and Cooper, O. Studies on the metabolism of adipose tissue. I. The effect of insulin on glucose utilization as measured by the manometric determination of carbon dioxide output. J. biol. Chem. 1959, 234, 774.

19. Beigelman, P. M. Assay of insulin and insulin-like substances: Method of glucose uptake by rat epididymal fat. Clin. Res. 1958, 6, 92.

20. Beigelman, P. M. Insulin-like activity of normal and diabetic human serum. Diabetes 1959, 8, 29.

21. Humbel, R. E. Messung der Serum-Insulin-Aktivität mit epididymalem Ratten-Fettgewebe in vitro. Experientia (Basel) 1959, 15, 256.

22. Jeanrenaud, B., and Renold, A. E. Studies on rat adipose tissue in vitro. IV. Metabolic patterns produced in rat adipose tissue by varying insulin and glucose concentrations independently from each other. J. biol. Chem. 1959, 234, 3082.

23. Milstein, S. W. Oxidation of specifically labeled glucose by rat adipose tissue. Proc. Soc. exp. Biol. (N. Y.) 1956, 92, 632.

24. Cahill, G. F., Jr., Leboeuf, B., and Flinn, R. B. Studies on rat adipose tissue in vitro. VI. Effect of epinephrine on glucose metabolism. J. biol. Chem. 1960, 235, 1246.

25. Winegrad, A. I., Shaw, W. N., Lukens, F. D. W., Stadie, W. C., and Renold, A. E. Effects of growth hormone in vitro on the metabolism of glucose in rat adipose tissue. J. biol. Chem. 1959, 234, 1922.

26. Karnovsky, M. L., Foster, J. M., Gibez, L. I., Hagerman, D. D., Robinson, C. V., Solomon, A. K., and Villee, C. Correction of factors for comparing activities of carbon-14 labeled compounds assayed in flow proportional counter. Anal. Chem. 1955, 27, 852.

27. Piazza, E. U., Goodner, C. J., and Freinkel, N. A reevaluation of in vitro methods for insulin bioassay. Diabetes 1959, 8, 459.

28. Hagen, J. M., Ball, E. G.; and Cooper, O. Studies on the metabolism of adipose tissue. II. The effect of changes in the ionic composition of the medium upon the response to insulin. $\mathrm{J}$. biol. Chem. 1959, 234, 781.

29. Ferrebee, J. W., Johnson, B. B., Mithoefer, J. C., and Gardella, J. W. Insulin and adrenocorticotropin labeled with radio-iodine. Endocrinology 1951, 48, 277.

30. Hill, J. B. The adsorption of $\mathrm{I}^{131}$ insulin to glass. Endocrinology 1959, 65, 515.

31. Snedecor, G. W. Statistical Methods Applied to Experiments in Agriculture and Biology. 5th ed. Ames, Iowa, The Iowa State College Press, 1956.

32. Jerne, N. K., and Wood, E. C. The validity and meaning of the results of biological assays. Biometrics 1949, 5, 273.

33. Miller, J. P., and Cooper, J. A. D. Lipogenesis by adipose tissue: Serum stimulating effects. Biochim. biophys. Acta 1959, 33, 436.

34. Moloney, P. J., and Coval, M. Antigenicity of insulin: Diabetes induced by specific antibodies. Biochem. J. 1955, 59, 179.

35. Leboeuf, B., Flinn, R. B., and Cahill, G. F., Jr. Effect of epinephrine on glucose uptake and glycerol release by adipose tissue in vitro. Proc. Soc. exp. Biol. (N. Y.) 1959, 102, 527.

36. Groen, J., van der Geld, H., Bolinger, R. E., and Willebrands, A. F. The anti-insulin effect of epinephrine; its significance for the determination of serum insulin by the rat diaphragm method. Diabetes 1958, 7, 272.

37. Leboeuf, B., and Cahill, G. F., Jr. Studies on rat adipose tissue in vitro. VIII. In preparation.

38. Engel, F. L., and White, J. E. Some hormonal influences on fat mobilization from adipose tissue. J. clin. Nutr. 1960. In press. 
39. Lynn, W. E., McLeod, R. M., and Brown, R. H. Effects of epinephrine, insulin and corticotrophin on the metabolism of rat adipose tissue. J. biol. Chem. 1960, 235, 1904.

40. Lee, H. M., Ellis, R. M., and Brower, W. W. Insulin-like activity of crystalline glucagon as measured with rat epididymal fat preparation. Proc. Soc. exp. Biol. (N. Y.) 1960, 104, 4.

41. Winegrad, A. I., Shaw, W. N., Lukens, F. D. W., and Stadie, W. C. Effects of prolactin in vitro on fatty acid synthesis in rat adipose tissue. J. biol. Chem. 1959, 234, 3111.

42. Jeanrenaud, B., and Renold, A. E. Studies on rat adipose tissue in vitro. VII. J. biol. Chem. In press.
43. Riet Correa, P., Magalhaes, E., and Krahl, M. E. Response of epididymal adipose tissue to small concentrations of insulin: Effect of cortisol. Proc. Soc. exp. Biol. (N. Y.) 1960, 103, 704.

44. Leboeuf, B., and Cahill, G. F., Jr. An in vitro effect of cortisol on ACTH or epinephrine stimulated adipose tissue. Reported to 42nd annual meeting of the Endocrine Society, Miami, June, 1960, page 60 of program.

45. Steelman, Sanford L., Oslapas, B. S., and Busch, Robert D. The in vitro inhibition by hydrocortisone of the action of insulin on adipose tissue. Reported to 42nd annual meeting of the Endocrine Society, Miami, June, 1960, page 91 of program.

46. Lee, H. M., and Root, M. Personal communication. 